\title{
Towards the Post-Human Body. On New Poetry and New Reality
}

Bogusława Bodzioch-Bryła 


\section{Towards the Post-Human Body. On New Poetry and New Reality}

DOI: 10.18318/td.2015.en.1.10

To be so close with the machine as to spend your entire life inside it

F. Zawada, Cywilizacja donos pierwszy

$\mathrm{n}$ his deliberations on the world of electronic media, Wolfgang Welsch contrasted them with the human body understood as a peculiar, inviolable sphere, existing in this particular respect as a sort of taboo.

The body is a conservative element, and it remains a condition for our every operation. From the philosophical side, the significance of corporality as a counter-balance to the electronic tendencies of immaterialization has been expounded repeatedly in the last few years. [...] But there is also a media intangibility, a sovereignty and obstinacy of bodies. These we are rediscovering today in a counter-move to the mediatization of the world. Think, say, of Nadolny's «discovery of slowness» or of Handke's praise of weariness. Amidst the turbulences of a world increasing its electronic potency the uniqueness of an unrepeatable hour of encounter is becoming important to us anew-or the inertia and the joy of a touching hand or a pair of eyes'.

1 Wolfgang Welsch, "Artificial Paradises? Considering the World of Electronic Media-and Other Worlds", in Undoing Aesthetics, (London: Sage Publications, 1997), 183-184.

\section{Bogusława}

Bodzioch-Bryła -

university lecturer at

the Institute of Cultu-

ral Studies of the Aka-

demia Ignatianum in

Kraków. Author of the

following books: $\mathrm{Ku}$

ciału post-ludzkiemu.

Poezja polska po 1989

roku wobec nowych

mediów i nowej

rzeczywistości; Kapłan

Biblioteki. O poetyc-

kiej i eseistycznej

twórczości Adama

Zagajewskiego;

Znowymi mediami

"w kulturze" $i$ "o kultu-

rze".Scenariusze zajęć

edukacji medialnej dla

nauczycieli; co-author

of Przepływy, protezy,

przedłużenia. Prze-

miany kultury polskiej

pod wpływem nowych mediów po 1989 roku;

Literatura i nowe

media. Homo irretitus

w kulturze literackiej

XX/XXI wieku. Contact:

boguslawa.bodzioch-

-bryla@ignatianum.

edu.pl 
Interactions with modern science and culture not only seem to disprove the thesis, they seem to render it invalid. The cultural change taking place in both philosophy and art, a process initiated years ago by the collapse of the idea of modernity, introduced the term posthuman into the general discourse, and thus touched upon the very essence of humanity and heralded transcendence beyond the accepted limits of its understanding. In performances aspiring to the rank of works of art, the human body undergoes a range of extreme treatments, including disassembly, hypodermic penetration, fragmentation, technologization, introduction into symbiotic bonds with artificial technologies, and thus ceases to be an untouchable organic whole and loses its prior inviolability. "New technologies extend and augment the human body and as such influence the shape of identity"2.

The real turning point transpired [...] with the advent of the electronic era and its crowning achievement: the computer. Using that particular invention, man decided to create, perhaps the ultimate, perfect machines in his own image, not physical ones as much as intellectual. Work on artificial intelligence enthralls both scientists and consumers of mass culture already densely populated with robots, androids, gynoids, and cyborgs. The latter bear the greatest resemblance to true human form due to their hybrid nature: they are an amalgamation of human and machine ${ }^{3}$.

As we stop to ponder the question of the artistic application of possibilities offered to us by technology, including photography or computers, we do not have to look any further than the work of Robert Mapplethorpe, Laurie Simmons (quasi-human figures immersed in water), Susan Wides (groups of wax figures in simulated relations), the "sculptured" self-portraits of Charles Ray (portrait-like reconstructions of the artist's head affixed to the body of a mannequin) ${ }^{4}$, or the performances of Stelarc, based on the exploration of the symbiosis between the flesh and the computer. The latter, an Australian artist, in his quest to make the body more compatible and to extend its sensory and reactive capabilities, seems

2 Ryszard W. Kluszczyński, "Ontologiczne transgresje: sztuka pomiędzy rzeczywistością realną a wirtualną", Kultura Współczesna 1-2 (2000): 194.

3 Monika Bakke, Ciało otwarte. Filozoficzne reinterpretacje kulturowych wizji cielesności, (Poznań: Wydawnictwo Naukowe Instytutu Filozofii UAM, 2000), 162-163. 
to have taken his art to the extreme and subjected his own body to external manipulation 5 .

During the performance, his consciousness controls only half of his body, the other half is moved from without. [...] the artist's physicality is cleaved in half: the head and the right part of his body reacts to signals flowing from his "internal consciousness", that is his brain, whereas the left is subordinate to external signals flowing from electrodes attached to the skin. An external consciousness controls the latter. The audience, using specially programmed computers and muscle stimulation devices, can program the motor input sequence to be performed by left side of the artist's body. Therefore, in his performances, Stelarc combines reactions to stimuli flowing from two sources in a single body. The audience controlling him can be either near the artist and program the choreographic directly by approaching the terminal $[. .$.$] or can do so remotely, via computer networks { }^{6}$.

The works of Konrad Kuzyszyn are another peculiar instance of the relevance of the topic of cultural experiences (manipulations) performed on the human body. In the "Condition" series, he created compositions that Monika Bakke labeled a sort of surreal anatomy or a bestiary.

5 For Stelarc, "what matters is a sort of global consciousness related to the capability to function remotely, the capability to connect (via the Internet) and interact in a multitude of ways, both with other people as well as remotely controlled robots and software. From this new perspective, the body becomes different from the idea of an organism defined along traditional lines. Stelarc believes, quite controversially, that a person's individuality is no longer paramount. The ability to communicate takes center stage, because only in communication with other bodies does the body acquire new power in this virtual structure. By inquiring whether it is important to stick by one's imperfect, deficient body, the artist explains that maybe the meaning of being human lies in refusing to remain just that. Thus, the artist joins others in asking: has man already become an anachronism, a vestige of bygone eras?

For Stelarc, the Internet is something more than just a means of storing and transmitting information. The artist believes that we may be developing strategies that establish the Internet as a sort of external nervous system, linking bodies serving as network nodes. [...] The Internet becomes this intelligent switching and linking system. This idea was implemented in one of Stelarc's performances, entitled «Ping Body». During the performance, hosted in Luxembourg, the artist subjected his body to electric stimulation flowing from three distinct sources: the Georges Pompidou Centre Georges Pompidou in Paris, the Media Lab in Helsinki, and the «doors of Perception» symposium that was taking place in Amsterdam at the time. The reactions of Stelarc's body were involuntary, controlled remotely by other people over great distances". Bakke, Ciało otwarte, 154

6 Piotr Krajewski, "Od reprodukcji mechanicznej do genetycznej", in Piękno w sieci. Estetyka a nowe media, ed. Krystyna Wilkoszewska, (Kraków: Towarzystwo Autorów i Wydawców Prac Naukowych Universitas, 1999), 242. 
The "Condition" cycle comprises small objects that one can fit in the palm of one's hand, usually made out of two Plexiglas plates holding between them a single photographic film frame that features the likeness of a human, or we should say, the likeness of something humanlike. Sometimes it is the human body multiplied, other times it is a body posed to resemble a human embryo, and still other times, only a fragment of the body is multiplied. This creates the impression of dealing with monstrously disfigured flesh, bodies that Nature has not separated properly, or with victims of some cruel genetic experiments. [...] Kuzyszyn created something akin to surreal anatomies or even a bestiary, as it is anomalies that blur the clearly delineated border between the human and the animal, and simultaneously reinforce other polarities: between the normal and the abnormal, the natural and unnatural, the good and the evil?.

All of these examples further confirm the notion of man expanding his area of interest; after exploring nearly every sphere receptive to his experience, he is now willing to expand it further by examining his own body and organism.

According to Jaron Lanier, one of the main creators and theorists of virtual reality, one of the most striking characteristics of the virtual world, a world defined by flexibility and the ability to shape it at will, is the fact that the border between the human body - the body of the user-and the rest of the world is fluid. In essence, from the perspective of virtual reality, the body can be defined as that portion of the reality that does not move with the speed of thought. In these circumstances, a precisely definition the boundaries of the body may turn out to be very difficult ${ }^{8}$.

When the partition between the human and the artificial finally collapses, all other dualisms will follow, polarities will become indistinguishable from one another, and man will be knocked down from the unique and privileged position that was bestowed upon him by Enlightenment philosophers. In point of fact, the transgression of boundaries is an essential feature of postmodernism, whereas the cyborg represents the ultimate transcendence of a specific boundary ${ }^{9}$.

7 Bakke, Ciało otwarte, 44 .

8 As quoted in Derrick de Kerckhove, The Skin of Culture: Investigating the New Electronic Reality, (Toronto: Somerville House, 1995).

9 As quoted in Bakke, Ciało otwarte, 155. 
These changes are obviously affecting the younger generation of poets. Some of their works definitely transcend Welsch's concepts we discussed earlier and seem to go hand in hand with the musings of contemporary aestheticians and cultural anthropologists, as they touch upon subjects that were not that long ago considered taboo, including the depersonification of human beings. Naturally, we will not use this space to investigate the effects of the more extreme treatments performed on the literary figure of the human body. I personally presume that what we are dealing with here is a sort of a prelude, a preface to the real and total unveiling of the body of the futurethe cyborg.

Breaching the boundaries of the body with the intention of disrupting its integrity is one of the symptoms of the breaking of the taboo. Peeking inside the body as if we would into the depths of a complicated mechanism, or observing it with an eye "equipped" with quasi-IT knowledge and terminology, seems to be a potential remedy for its numerous ailments. In the era of the biotechnology syndrome, the body in the traditional sense becomes something of a vestige, its meager durability and poor resistance to external factors gradually invalidating its raison d'être.

That particular way of thinking about one's flesh is fairly evident in one of Marcin Baran's poems:

The cough raises my blood pressure, clamps

my brain. My heart cracked, the skin

on my head taut $[\ldots]$

My hands swell in my sleep.

[...]

Face bloated

in the morning, the skin between my skull

and my scalp is burning. As long as the organs work, the exterior

can be whatever it wants-in anticipation

of terrible pain

[Marcin Baran, Ciało]

as it is in Majzel's work:

this morning I found blood seeping out.

$[\ldots]$ a hematoma is blooming inside, the little growth.

the feral, migratory creature.

let's call it a hematoma, 'cause the doctor's comforting.

$[\ldots]$

maybe it's not a tumor but a garden,

silence slowly shrouding it? 
$[\ldots]$

and life? it'll show up.

somewhere north of the navel.

wild orchards will overgrow us.

a sensitive yet colorless fur.

The perception of bodies and corporeality as irremovable obstacles that simultaneously are inherent attributes of humanity also shines through in the work of Biedrzycki:

this frost grinds my teeth and grates my enamel

my desiccated eyeballs knocking around the too big

sockets. Wherever I go, I carry with me on a glass neck

a skull filled with metal bees

$[\ldots]$

March has come and pierced me with its eyes

bright with fever

[Miłosz L. Biedrzycki, oczy błyszczace]

"Only how long / can this electoral machine of the body / will keep stuffing bloody votes into the urn of my heart?", asks Marcin Baran, prefacing the question with a poetically ascetic account of the clash between his lyrical self and his, shall we say, machinery, a description of the limitations of the human mind rooted in corporeality. The rhetorical question requires no answer but a negative reply seems obtrusively self-apparent.

Poets of the younger generation try to tackle the matter of flesh as a source of ceaseless trouble and worry. The environment which man inhabits-the surrounding reality described in postindustrial categories-tries to suggest to him a possible remedy to spiritual and bodily ailments that trouble him. This reality was the origin of the image depicting man as an amalgamation of elements hailing from different sources that was eventually transplanted onto poetic ground.

Man as automaton, a mechanism resembling multitudes of technological creations filling our civilizational space in both form and function-a picture like that is far from rare, especially in fragments that describe the confrontation between the lyrical self and one's own consciousness, the latter entangled in relationships within its immediate proximity:

I walk from room to room. The shadow follows me, uncertain. I water the flowers, sweep the dust, drink, swallow.

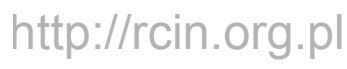


The Earth turns, its gears sluggish, drifting to the port of the calendar page, the day already pulling the handbrake in the parking lot of the night. Sentences tumble out lopsidedly, as if from a jammed hurdy-gurdy. I'm still feigning words, actions, gestures.

The typewriter binds them together.

[Grzegorz Olszański, Zżyciowych problemów nieżyciowych facetów. Część pierwsza, nieostatnia]

The automation of the human body and its reflexes is accompanied here by a peculiar feeling of amalgamation with the typewriter, a technological creation of man, which leads, in turn, to inauthentic behavior; lest we forget, "feigning" implies dissemblance, simulation and deception.

This specific character also leaves its mark on spaces more distant than one's own room, spaces which entangle the lyrical protagonist within a web of situations and dependencies related to institutions or governments:

The clerk receives and disburses

funds, raises and lowers

her head.

[...]

The cashier's fingers are faster than numbers.

[Grzegorz Olszański, Zżyciowych problemów nieżyciowych facetów. Część druga, bez pokrycia]

Poetry of the new generation often employs the notion of man constructed in the image of a multiple choice machine:

What we did, we could have done differently

[Grzegorz Olszański, Wyjście z okręgu]

or man as automaton wholly devoid of any human characteristics, working with computerlike precision and rhythmicalness:

Memory catalogs holding the exact

amount of dust and number of stains, the place learned by rote.

Simple sentences. Complex problems. [...] The cadaver awaits.

Renews, repeats. 
The human automaton usually possesses a mind structured like a computer's central processing unit.

...interactive memories

launched by pointing the memory cursor towards the appropriate word or gesture.

[Grzegorz Olszański, Narodziny tragedii, Sztuka mięsa]

The virtualization process, however, touches more than just the body. Even more prevalent is the issue that we might classify as the interrogation of identity, and of the subject "becoming dispersed, decentralized, inconsistent, we might even say consumed by the interface"10.

As the image of the integral organism is gradually "replaced with the notion of an incoherent body, constantly enhanced and reconditioned-constantly on the lookout for new identities, permanently dissatisfied with itself"11, we can surmise that the mental disposition of the lyrical "self" finds itself in a similar situation, and it is in this light that we see the subjects of these poems.

The disintegration of the bodily image [...] puts the subject in danger of returning to realms not yet under the influence of the conceptual order, that is returning to an archaic, disassembled, uncoordinated body, a body dissimilar from itself. The return to the realm of the real order may elicit psychotic fantasies revolving around disintegration and surrendering oneself to the authority of the external world-the objective world.

In the widespread fascination with the images of the human body, Lacan sees the expression of a desire for a strong and stable identity. The image that the subject wants to associate with reinforces its position in the imaginary and symbolic sphere against the dangers lurking within itself. The subject permanently retains what we may label the sediment of prior corporeal experience in fragments that appear in dreams about the disintegration of one's body and, in extreme cases, in psychotic depersonalizations $\mathbf{1 2}^{\mathbf{2}}$.

10 Agnieszka Ćwikiel, "Metafora cyborga-ciało przyszłości", Kultura współczesna 1-2 (2000): 161.

11 Adam Paluch, "Wizerunek nasz, czyli ciało na scenie ponowoczesności", in Transformacja, ponowoczesność wokół nas i w nas, ed. Adam Paluch (Wrocław: Katedra Etnologii Uniwersytetu Wrocławskiego, 1999), 129. 
It also turns out that it is possible to look from another perspective at the role of media integrated with the human body and their influence on the structure of the human organism, which, as a result, no longer seems to be a fully autonomous entity. The notion of media functioning as a sort of "prostheses" that extend and augment the body of the modern human being is espoused by numerous scholars, including Lyotard, Virilio, and Welsch ${ }^{\mathbf{1 3}}$.

The electronic media insert us into a world moving at the speed of light, a speed that our senses are simply not designed to handle. Therefore, media art should take on the task of adapting humanity to function at these breakneck speeds. That is the direction Lyotard took with his 1985 exhibition, as did Virilio and Welsch-by depicting changes taking place in the sphere of human perception (the vanishing constitutes part of the phenomenon, the anaesthetic determines the aesthetic). In this option, the media are considered an extension of the body, an augmentation of the body's sensory capabilities, an enhancement of the human aisthesis. The media become prostheses that allow us remote vision and hearing. [...] Even McLuhan himself has described the media as man's sensory prostheses. They introduce both quantitative and qualitative changes into prior frameworks of human perception. Thanks to the media, we perceive more and we perceive differently ${ }^{14}$.

As noted by Monika Bakke,

we ceaselessly enhance our capabilities, we boost and sharpen our memory, our vision, hearing, olfaction. Newer and newer technologies revamp our bodies increasing our dependence on them [...] We are already used to the idea of miniature electronic devices buried deep inside our body, facilitating its survival. They are invisible to the naked eye, hidden, and they blend in perfectly with their organic surroundings. The scope of this expansion is impossible to ignore, we are already past a very significant boundary-until very recently, technology was still external, still part of the landscape, the environment, and not the body ${ }^{15}$.

13 Krystyna Wilkoszewska, "Estetyki nowych mediów", in Piękno w sieci. Estetyka a nowe media, ed. Krystyna Wilkoszewska, (Kraków: Towarzystwo Autorów i Wydawców Prac Naukowych Universitas, 1999), 22. 
These notions have also led to the rise of new fields of study, including neuroaesthetics, a discipline based on the idea of a cybernetic network comprising both human organs and microprocessors. ${ }^{\mathbf{1 6}}$ Virilio perversely considers the disabled person overcoming their limitations with the help of technology to be the ideal of a healthy human. The difference lies in the fact that paraphernalia once considered external prostheses (glasses, crutches) or even animal organs transplanted into humans are now supplanted by miniature hardware-gear that Virilio calls (electro)technical prostheses ${ }^{\mathbf{1 7}}$.

We should take a step back here and ponder the matter of the scenery that accompanies the average user of the modern world in the exact moment that we might consider the definitive "here and now". Here is one example of reality constructed by Lekszycki:

I wake up in a cold room, my anxiety

recognizes me in the mirror. to start the day well,

I remind myself of the end-the scene with the woman

giving me the cold shoulder.

a low scoring average won't give me a career in Zepter Idea Śląsk

Wrocław, not even my

high school basketball team.

no, it doesn't hurt me at all.

I still have my Technics stereo,

a six-head Thomson VCR,

and I still can add some memory

to my PC, swap out the CPU,

Grundig allows me to watch the coverage

of the Four Hills Tournament and be moved

when adam małysz

leaves behind his rivals, gliding to $133 \mathrm{~m}$. after achieving

92.5kph on the threshold, and so I can fly

from my apartment doors into the murky void

outside-and glide 200 meters to the kiosk.

to buy cigarettes and a puzzle set with naked ladies

[Paweł Lekszycki, ckliwy wiersz o samotności i pustce, której nie wypełni drogi sprzęt audio-video ani nawet mitość narodu polskiego do adama małysza]

16 Wilkoszewska, "Estetyki", 23.

17 Ibid., 23. 
The reality put together by Lekszycki often turns out to be completely artificial, a conglomerate of conduits that may have mediated contact with the real, external world, were such a world to exist. However, the virtual conglomerate (the audio-video composite) seems to be the only definitely true element, while Lekszycki himself is surrounded by nothingness, nonexistence, this "murky void". The genuine original of the world does not exist, only its fragments do, copied and conserved in the bowels of complex mediation machines. It is no wonder then that man himself is also practically a nonentity; in its place there is only a creature whose body was enhanced by flawless prostheses. If we are to listen to music, we should only do so using a Technics stereo, view the world only through a TV screen, store memories only in the memory of a computer. A "Technics stereo", a "Thomson VCR", a "PC central processing unit", a TV set-all of them prostheses of modernity-these are the only things that truly exist. Every attempt to go "beyond" means entering an uncertain area that touches directly upon personal reflection and experience which, in turn, puts one at risk of falling into the "murky void" of unknown extraction.

Dwelling in the virtual expanses of the Internet is extremely tempting, especially given the unlimited possibilities in terms of generating new realities. In a demiurgic gesture of creation, Lekszycki designs a world that is the total opposite of the realities of spaces we label with the prefix "cyber-":

sun filtering through the blinds. the ceiling

is my sky, when building walls

I discover the power to

spread fire and quake the earth.

tornadoes obey me.

the rivers as well.

as does the bourgeois mob.

my whispers ignite

the first flashes of disquiet and rebellion.

my words quell all insurrection.

also in my hands: improving education

or fostering crime. years of plenty, years of famine.

it's my privilege to raise taxes.

I unleash monsters upon cities and then kill them dead.

I'm the wellspring of entertainment and labor. a patron of the arts.

it's my world, so don't mess with my head.

don't talk to me about the examination of the divine

in modern poetry. never try to scare me 
with death. I know all the god mode cheat codes.

enter.

We are dealing here with a situation where, probably under the influence of a computer game, the consciousness of the lyrical protagonist impersonates a godlike creator entity that dreams up realities at will, with the verbal equivalent of the act of creation-the Biblical "let there be light" - replaced by Lekszycki with the far more computerlike "enter". We should take notice of the extensive usage of the personal and possessive pronouns - "I" appears over thirteen times. The poem becomes something of a manifesto of the modern man, someone claiming to be subject to no limitations, but the manifesto is a dangerous one-it ends with an ambiguous and ominous "enter", a gesture one might mistake for an extermination order.

The magical "enter" reveals [...] to the stranger new avenues in a potentially interminable journey, new possibilities that emerge in the drift through messages and cultures, and countless interactions with thousands of Internet users. There are no dead-ends in cyberspace, each click of the mouse is but a prelude to the next one. Simultaneously, categories like linearity or consequentiality lose their meaning in its depths: $\mathrm{B}$ does not necessarily have to come after A, and C after B. You can "click" forwards, backwards, up, down, sideways; G, S, even (-6) or (***) can come after A. You can swap out and combine logics and conventions. There are no limits or demarcations, everything here can lead to everything else and intermingle with everything else. Here, intertextuality becomes hard fact ${ }^{18}$.

We should ponder the change in the meaning of the term, which seems to acquire new, additional significance in the context of the aforementioned Lekszycki poem: the word "enter" is now more than a simple computer command, it is a godlike gesture used to demonstrate one's own power.

"I hear a command flowing from the holy screen", writes Tadeusz Pióro in his poem Najawie. Also in this case, the lyrical "self" seems to exist in a reality that we may as well affix with the prefix "cyber". This nearly surreal world is a conglomerate of artificiality:

18 Agnieszka Gromkowska, "Tożsamość w cyber-przestrzeni-(re)konstrukcje i (re)prezentacje", Kultura Współczesna 3 (1999): 37. 
We sat in a forest with a basket full of sandwiches, a thermos with spiked tea, $[. .$.

One day, however, all the leaves

were knocked down by a violent wind:

apples of Eden here and there on the branches:

we found ourselves in a symbolic impasse.

Only recourse was to go on a shopping spree

credit card holograms

glimmered like ornaments on a Christmas tree

[...]

the polygraph refused to cooperate

and we failed the memory test.

[Tadeusz Pióro, Daj mi tam gdzie nie myślę, Wola i ochota]

An innocent stroll through the forest suddenly transitions into a walk through the woods of fiction, while the script for this particular metamorphosis only partially resembles an apocalyptic scenario. The realm of nature is promptly replaced by a space resembling the crowded corridors of huge malls experienced during outings dominated by "shopping sprees", the "glimmer of credit card holograms". Because the "polygraph refused to cooperate", and the "memory test" ended with failure, there is no way for us to invoke and refer to notions like the "Beginning" or "Truth". Therefore, Pióro deceives us when he writes:

there is a way out from under this pile of prostheses

[...] the procedure is simple

record your voice after the signal.

Call you back as soon as I get back from the void

[Tadeusz Pióro, Dajmi tam gdzie nie myślę]

The signal, as it turns out, does not come from the beyond at all, as the only signal is the beep of the answering machine-a very special form of falsity: a voice separated from its owner, a word separated from the person uttering it (akin to Logos without God?). It is a shift in both time and space. It seems that the void of the information channel is our way out from under the "pile of prostheses", a situation wherein the Sender and the Recipient are not bound in the act of communication, and immediacy will not act between one and the other. This, in turn, violates the traditional structure of the act of communication, as it eliminates the one seemingly essential element of the process, that is contact.

Dread is pervasive in virtualized reality. The comfort of Internet immediacy has a way of promptly turning into a source of discomfort.

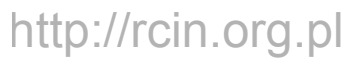


Given the Internet's public and ubiquitous character, protecting one's privacy is becoming increasingly harder. It turns out that even one's most intimate experiences can become the subject of public discourse. There is no private space-time, neither is there a wholly private domicile. There is, however, the screen and the web: a computer in front of which thousands of people sit simultaneously, all of them invisible but ready to observe ${ }^{19}$.

George Kateb turns our attention to the modern tendency of exposing oneself to public view, the desire to be observed. Four factors can be deemed responsible for this state of affairs, these being: the social nature of man, sociability specific to democracies, democratic exhibitionism (its symptoms include the incredible popularity of talk shows), and democratic theatricality ${ }^{20}$.

Not every individual will experience the carefreeness of satisfying "the craving of the eyes". Under these exhibitionist conditions, amidst thousands of webcams, many of them often installed in private apartments, it is fairly easy to feel kept under surveillance. These feelings also accompany the lyrical protagonist in the works of new generation poets, they are rooted in the protagonist's mind and in time grow to be an indispensable constituent of his disposition. In poetry, they sometimes take the shape of a sneaking suspicion, one reeking vaguely of conspiracy theories, that one is being watched, spied upon, even followed or imitated:

\section{...I sit here}

and watch: the laundry I hung earlier imitates

towels from commercials and starts to strip

sensually shedding clothespins, people at the store

imitate the protagonists of modern poetry,

the neighbor imitates Kim Basinger

in the scene with Cocker playing in the background.

Then she leans out the window

and does the same thing I do.

[Grzegorz Olszański, Sny, Słowa. Pojedyncze zdania, złożone problemy]

In Grzegorz Olszański's work, this specific discomfort takes the shape of an overwhelming feeling of inertia, a dangerous thickening of air that inspires a fishlike gasping for air:

19 Anna Błaszczyk, "Przestrzeń w wymiarze wirtualnym", in: Przestrzenie, miejsca, wędrówki: przestrzenie w badaniach kulturowych i literackich, ed. Piotr Kowalski (Opole: Wydawnictwo Uniwersytetu Opolskiego, 2001), 73-74. 
The snow melted long ago. Now it's the asphalt, melding with the wheels of truck [...]

The stocks of air have skyrocketed at the meteorological stock market, some of them vanished, others shredded by blades Of ventilators [...]

The radio, the $\mathrm{TV}$, the press will surely make a big deal out of it. Already the air is thick in my throat, [...]

At night, the writing on the wall will come alive with fresh paint [...]

"Give me some air"-a scream erupts, radio waves billowing and drifting away with it into the ether. [...]

The screaming will stop.

The day will overexpose the curtains. Lungs will slowly turn to gills.

[Grzegorz Olszański, Wakacje w mieście. Walka o oddech]

In Olszański's poem, the air is thick not with heat but with excess ("blades of ventilators", "the radio, the TV, and the press", fresh paint of the "writing on the wall", "radio waves", the "ether"), making it useless, making it impossible to breathe, closing the larynx. The presence of the protagonist can be felt only between the lines. No entity deriving from outside the space-time dominated by elements of the techne realm can exist within it. That is the reason for the impersonal character of oblique verses that seems to suffuse the entire poem. In her ruminations on the subject of crowds and urban density, Jolanta Brach-Czaina acknowledges the experience of density to be an essential element of our world, and she includes both population density-with street traffic and mobs swarming in buses and subway cars-and the accumulation of a large number of individual objects in a small space in the term's semantic field. Density also encompasses the rush of information and symbols we associate with categories like commodity abundance, as well as the surge of activities, experiences, stimuli, and even sounds, in other words a multiplication of sensations that is so cherished by modern societies ${ }^{21}$.

The results of this swarming include the perception of reality as a conglomeration of secret arrangements, secret objectives, and secret undertakings, all

21 Jolanta Brach-Czaina, "Gęstość, tłok, miasto", Res Publica Nowa 2 (2002): 54-58. 
of them part of a giant conspiracy spun by the (post)modern world aimed against every individual being:

suddenly I thought

about all these

facilities

ready to turn you into a corpse

and open all night long

[Grzegorz Olszański, Hades zaprasza]

Filip Zawada reaches the pinnacle of suspicion in his poem Plakat:

It was already dark when I saw the poster

calmly fluorescent

CAMPS FOR CHILDREN

with German lessons

[Filip Zawada, Plakat]

The particular brevity of the poet makes the reader question whether only the poster is fluorescent in the scene. The unspoken contamination of phrasemes (a language immersion camp and a concentration camp) is provoked by an involuntary procession of associations: the term "fluorescent" may be included in the semantic field of the term "phosphorescent", which in turn may invoke connotations of experiments on humans conducted in death camps.

The stifling atmosphere in the poems of Eugeniusz Tkaczyszyn-Dycki resembles the insides of the schizophrenic personality of the modern man, a person who on one the hand recognizes the dangers of becoming too dependent on specialized surrogates of human beings - machines, while on the other hand is paralyzed by a fear of what seems to be unknown, alien and free of the processed cud of popular culture.

What will happen to us once we finally learn when they'll disconnect us from or reconnect us to the oft-faulty medical equipment in the regional hospital where everything seems broken except the nurses

[Eugeniusz Tkaczyszyn-Dycki, Na korytarzu szpitala wojewódzkiego]

In Virtual reality, Miłosz Biedrzycki's important examination of the changes that our modern reality is undergoing, the author investigates the oft-discussed problem of authenticity and derivation, or more precisely-the limits

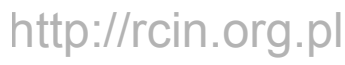


of simulation and whether their crossing makes it impossible to discern the real from the virtual. Virtual reality seems to directly correspond with Baudrillard's concept of hyperreality of the modern world, the world of simulation and simulacra, the world in which all referentiality has been abolished and reality exists only as an artifice recreated in signifying systems ${ }^{\mathbf{2 2}}$.

I walk \& admire the precision with which it was made

the pressure on my sole in the exact moment

when my foot touches the sidewalk

turn my head a bit and I look at

another piece of the image. [...]

the dust, the whirling-reconstructed

very realistically. [...]

the same hippies on drums I saw last spring

even the rhythm's the same. maybe blood-only

the servile processor suggests the images

at will: bongo drums, hair, summer

dresses of the girls - so the sensations stay

consistent. a stripling walks among the audience, drum turned

over, collecting change. I put two thousand in, he looks at me,

mumbles: fanks. fanks? what is this?

they could have dialogue in polish.

whatever-it's probably a pirated copy, anyway.

[Miłosz L. Biedrzycki, Virtual reality]

The image of the human body in this poem is focused particularly on its natural functions and activities, which in turns gives the impression that sensory perception is not something ascribed to the human body by physiology and

22 Baudrillard envisions modernity as reality that is reproducible, simulable, and hyperreal. It is, in Baudrillard's words, "produced from miniaturized cells, matrices, and memory banks, models of control-and it can be reproduced an indefinite number of times from these. It no longer needs to be rational, because it no longer measures itself against either an ideal or negative instance. It is no longer anything but operational. In fact, it is no longer really the real, because no imaginary envelops it anymore. It is a hyperreal, produced from a radiating synthesis of combinatory models in a hyperspace without atmosphere. [...] It is no longer a question of imitation, nor duplication, nor even parody. It is a question of substituting the signs of the real for the real, that is to say of an operation of deterring every real process via its operational double, a programmatic, metastable, perfectly descriptive machine that offers all the signs of the real and short-circuits all its vicissitudes. [...] A hyperreal henceforth sheltered from the imaginary, and from any distinction between the real and the imaginary, leaving room only for the orbital recurrence of models for the simulated generation of differences". Jean Baudrillard, Simulacra and Simulation (Ann Arbor: University of Michigan Press, 1994), 2-3.

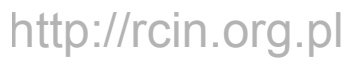


thus its inherent element by natural law, but rather an artificially added function, installed like an external piece of software ("the pressure on my sole in the exact moment/when my foot touches the sidewalk/turn my head a bit and I look at/another piece of the image"). This, in turn, leads to the likening of the structure of the lyrical protagonist to that of a piece of hardware-a simulator of the human organism (unnaturally lagging movements, interactive vision function with limited capabilities allowing only partial perception of the visual input with the role of the eyeball assigned to a device similar to a microprocessor handling image projection).

We live in a world transformed and undergoing transformation, the boundary between the real world and the virtual reality of the media its most sensitive spot. The threshold, at the same time ubiquitous, spatial, temporal, as well as processual, unconstrained by neither space nor time, confines man's existence to a peculiar set of interspaces and intertemporalities, to a hybrid world "in-between" - not only between civilizations and cultures, but primarily between reality and virtuality ${ }^{23}$. A quote from Umberto Eco seems to perfectly encapsulate the sentiment:

Once upon a time there were the mass media, and they were wicked, of course, and there was a guilty party. Then there were the virtuous voices that accused the criminals. And Art (ah, what luck!) offered alternatives, for those who were not prisoners of the mass media. Well, it's all over. We have to start again from the beginning, asking one another what's going on ${ }^{\mathbf{2 4}}$.

Translation:Jan Szelagiewicz

23 Kluszczyński, "Transgresje", 192-193.

24 Umberto Eco, Travels in Hyperreality (San Diego: Harcourt, 1985), 150. 